\title{
THE EFFECT ON REPRODUCTION IN FEMALE RABBITS OF ANTIBODIES TO A SPECIFIC AUTOANTIGEN IN THE SECRETIONS OF THE MALE ACCESSORY SEX GLANDS
}

\author{
R. J. ABLIN,* P. GUINAN AND I. M. BUSH \\ Immunobiology Section and Center for the Study of Prostatic Diseases, \\ Division of Urology, Cook County Hospital and Graduate School of \\ Medicine, The Hektoen Institute for Medical Research, Mount \\ Sinai Hospital Medical Center and Departments of Microbiology \\ and Urology, Chicago Medical School/University of Health Sciences, \\ Chicago, Illinois, U.S.A.
}

(Received 26th November 1973)

\begin{abstract}
Summary. Inoculation of female rabbits with 'coagulo-prostatic fluid' $(\mathrm{CPF})$, a secretory-specific autoantigen of male accessory sexual glands, permitted the identification by the methods of gel precipitation and passive haemagglutination of tissue- and species-specific antibodies to CPF. Subsequent mating of females with high titres of circulating antibodies to $\mathrm{CPF}$ at the time of coitus resulted in impairment of reproduction in three of four animals studied.
\end{abstract}

\section{INTRODUCTION}

The development of an immunological response characterized by the presence of circulating antibodies to secretions and tissues of the accessory sex glands of male rabbits by means of parenteral and/or cryo-(freezing in situ) stimulation has provided a method whereby the antigenic properties of these constituents may be investigated (Ablin, 1974).

Recent observations on the excretion of antigens of the male accessory sex glands in the urine and their possible presence in ejaculated semen (Barnes, 1966; Rosenmann, Dishon \& Boss, 1969; Dishon, Rosenmann, Durst \& Boss, 1970; Rosenmann, Dishon, Durst \& Boss, 1970) have directed attention to the rôle of such antigens in immunological phenomena connected with the reproductive process. As these accessory gland antigens are specific to the male, the possible effects on reproduction should the female become sensitized to them by way of the uterus and vagina (Behrman \& Otani, 1963) and the peritoneal cavity, especially following coitus, would be of considerable interest. The development of antibodies in does to a secretion of the buck coagulating (anterior prostate) and prostate glands termed 'coagulo-prostatic fluid' (CPF-Ablin, Pfeiffer,

* Correspondence: Dr R. J. Ablin, Immunobiology Section, Division of Urology, Cook County Hospital, Chicago, Illinois 60612, U.S.A.

H 
Gonder \& Soanes, 1969) possessing the major soluble antigenic components of these two accessory glands of reproduction (Ablin, 1973) and their subsequent effect on reproduction are evaluated in the present report.

\section{MATERIALS AND METHODS}

Coagulo-prostatic fluid and saline extracts of coagulating gland tissue (CGE) were prepared as described by Ablin (1973). Samples of other accessory gland tissues or fluids and of other rabbit tissues were also prepared as described (Ablin, 1973), as well as those of canine and human prostatic tissue and prostatic fluid.

Antisera to CPF were prepared (Ablin, 1973) in New Zealand albino rabbits. Two additional adult does were inoculated with CPF. When required, absorption of antisera was completed by the addition of various amounts of freezedried preparations of rabbit fluids or tissues as detailed by Ablin, Bronson, Soanes \& Witebsky (1970).

Serum specimens were evaluated for antibody reactivity by gel diffusion precipitation and by direct and indirect inhibition of tanned cell haemagglutination as described by Ablin et al. (1970).

To evaluate the subsequent effects of antibodies to CPF on reproduction, does, previously inoculated with CPF and shown to possess antibodies to CPF, were mated 28 days after their initial inoculation. This period of time was selected to coincide with the time of maximum antibody production as determined by titration of the haemagglutinating activity of antibody to CPF in sequential weekly serum specimens obtained from the inoculated animals.

\section{RESULTS}

\section{Immunological studies}

Isoimmune sera from each of the four does inoculated with CPF precipitated with CPF and CGE, forming a reaction of partial identity. Subsequent absorption of anti-CPF sera with CGE resulted in removal of the line of precipitation between anti-CPF and CPF. The specificity of this latter line of precipitation for CPF was verified by its removal following absorption of anti-CPF sera which had been previously absorbed with CGE and CPF. No precipitation occurred between anti-CPF and preparations of other rabbit accessory gland fluids or tissues or with those of other rabbit tissues, i.e. kidney, liver or testis, or with canine or human prostate or prostatic fluid.

Evaluation of anti-CPF sera by direct haemagglutination disclosed a rather sharp rise in the titre of antibodies to CPF and CGE, reaching a maximum titre at 27 days following initial inoculation. In contrast to gel precipitation studies, anti-CPF also reacted with seminal vesicle contents and 'total accessory sex glands', i.e. an extract prepared from seminal vesicle, coagulating, prostate and bulbo-urethral glands, at titres ranging from $1: 20$ to $1: 80$. No agglutination was observed, however, with preparations of other individual accessory gland fluids or tissues, with other rabbit tissues or with canine or human prostatic tissue or prostatic fluid. 
The tissue- and species-specificity of anti CPF sera as determined by direct haemagglutination reactions was confirmed by inhibition of haemagglutination, with the exception that rabbit prostate slightly inhibited the reaction between anti-CPF and CPF. This finding suggests the failure of extracts of prostate to become adsorbed on to the surface of tanned red blood cells in the direct haemagglutination test.

A comparison between the development and intensity of precipitating and haemagglutinating antibodies to CPF elicited in the female and in the male is shown in Table 1. The doe appeared to yield precipitating antibodies approximately 7 days earlier than the buck and generally possessed higher haemagglutinating antibody titres.

Table 1. Comparison of precipitating and haemagglutinating antibody to rabbit CPF in male and female rabbits following isoimmunization with CPF

\begin{tabular}{|c|c|c|c|c|}
\hline \multirow[b]{2}{*}{$\begin{array}{l}\text { Days after } \\
\text { inoculation }\end{array}$} & \multicolumn{2}{|c|}{ Bucks } & \multicolumn{2}{|c|}{ Does } \\
\hline & $\begin{array}{c}\text { No. developing } \\
\text { precipitating antibody }\end{array}$ & $\begin{array}{l}\text { Range in } \\
\text { haemagglutination titre }\end{array}$ & $\begin{array}{c}\mathcal{N} o \text {. developing } \\
\text { precipitating antibody }\end{array}$ & $\begin{array}{l}\text { Range in } \\
\text { haemagglutination titre }\end{array}$ \\
\hline $\begin{array}{r}0 \\
7 \\
13 \\
20 \\
27\end{array}$ & $\begin{array}{c}0 \\
0 \\
0 \\
1 / 2 \\
1 / 2\end{array}$ & $\begin{array}{l}\quad<10^{*} \\
40 \text { to } 160 \\
1280 \text { to } 2560 \\
1280 \text { to } 5120 \\
5120 \text { to } 20,480\end{array}$ & $\begin{array}{c}0 \\
0 \\
2 / 4 \\
4 / 4 \\
4 / 4\end{array}$ & $\begin{array}{c}<10 \\
80 \text { to } 160 \\
2560 \text { to } 5120 \\
10,240 \text { to } 81,920 \\
10,240 \text { to } 163,840\end{array}$ \\
\hline
\end{tabular}

GPF $=$ coagulo-prostatic fluid.

* Recorded as the reciprocal of the highest dilution of serum that reacted.

\section{Effect of antibody on reproduction}

Two of the rabbits exhibiting anti-CPF haemagglutinating titres of $1: 81,920$ and $1: 163,840$ on the 27 th day after inoculation failed to become pregnant despite being kept with two different mates over a period of approximately 5 weeks. The remaining two, possessing anti-CPF titres of $1: 10,240$, conceived, but in one doe, all except one of the young died within 48 to $72 \mathrm{hr}$ of birth.

\section{DISCUSSION}

In the present study, evaluation of the development and tissue- and speciesspecificity of antibodies in female rabbits to CPF was essentially identical to that observed in male rabbits inoculated with GPF (Ablin, 1973), except for a greater variation in the onset and intensity of the response in the does. A recent report describing the development of antibodies to CPF following heteroand isoimmunization (Ablin, 1973) has dealt quite extensively with questions of tissue- and species-specificity and the relevance of parenterally developed antibodies to CPF and of antibodies to CPF developed as a result of cryostimulation (Ablin, Witebsky, Jagodzinski \& Soanes, 1971). As the response to a given antigenic stimulus has been shown to be genetically determined and to vary among individuals of the same species (Grabar \& Williams, 1953), the interpretation and significance of differences in the intensity of the immune response to CPF noted between males and females should be viewed with 
caution, particularly in view of the limited number of animals evaluated in the present report.

The presence of antibodies to CPF in female rabbits at the time of coitus appeared to have a deleterious effect on reproduction directly in at least two and possibly indirectly in one of the four antibody-bearing animals. These findings are perhaps in keeping with those recently described by Rosenmann et al. (1971) and those of earlier reports which demonstrated that hypersensitivity to spermatozoal or seminal antigens caused infertility, e.g. guinea-pigs inoculated with epididymal spermatozoa or testis homogenate developed antibodies (Behrman \& Otani, 1963; Otani, Behrman, Porter \& Nakayama, 1963) which resulted in impairment of reproduction. As the stage(s), i.e. insemination, gestation, etc., at which the apparent impairment in reproduction in animals possessing antibodies to CPF occurs is not known, the following points require further investigation. (1) The importance of the seminal vesicles and coagulating gland and their secretions to reproduction in the rodent has been established (Greenstein \& Hart, 1964), but must be similarly established in the rabbit. In particular, the specific effect of antibodies to CPF on secretions essential to reproduction must be explicitly delineated. (2) The relationship of CPF to the heat-labile vesiculase secreted by the coagulating gland of the rat and guinea-pig (Camus \& Gley, 1899) or to the kallikrein-like toxic enzyme 'cobayin' present in the seminal vesicles, coagulating and prostate glands of the guinea-pig (Freund \& Thompson, 1957) should be established. The possibility of the potential immunopathogenicity of antibodies to such a potent toxin on reproductive processes remains to be determined. (3) The results of the present study, as well as those of Rosenmann et al. (1971), raise speculation on the existence of a hypersensitive state due to the presence of the cross-reactivity of antigens of seminal plasma and CPF in patients with diseases of the prostate and the possible relationship of such a state to infertility (Flocks, Bandhaur, Patel \& Begley, 1962).

\section{ACKNOWLEDGMENTS}

This research was supported in part by a grant from the John A. Hartford Foundation, Inc. during the appointment of R.J.A. as Director, Division of Immunology, Millard Fillmore Hospital, Buffalo, New York.

\section{REFERENCES}

AbLIN, R. J. (1973) Immunologic studies of the rabbit coagulating gland and its secretions. Biol. Reprod. $8,327$.

Abuin, R.J. (1974) Immunologic properties of sex accessory tissue components. In Structure and Functions of Male Sex Accessory Organs. Ed. D. Brandes. Academic Press, New York.

Ablin, R. J., Bronson, P., Soanes, W. A. \& Witebsky, E. (1970) Tissue- and species-specific antigens of normal human prostatic tissue. J. Immunol. 104, 1329.

Ablin, R. J., Pfeiffer, L., Gonder, M. J. \& Soanes, W. A. (1969) Precipitating antibody in the sera of patients treated cryosurgically for carcinoma of the prostate. Expl Med. Surg. 27, 406.

Ablin, R. J., Witebsky, E., Jagodzinski, R. V. \& Soanes, W. A. (1971) Secondary immunologic response as a consequence of the in situ freezing of rabbit male adnexal glands tissues of reproduction. Expl Med. Surg. 29, 72.

Barnes, G. W. (1966) Observations on prostatic antigens in blood and urines. Fedn Proc. Fedn Am. Socs exp. Biol. 25, 355, Abstr. 
Behrman, S. J. \& Otani, Y. (1963) Transvaginal immunization of the guinea pig with homologous testis and epididymal sperm. Int. F. Fert. 8, 829.

Gamus, L. \& Gleey, E. (1899) Action coagulante de liquide de la prostate extrême du hérisson sur le contenu des vesicules séminales. C.r. hebd. séanc. Acad. Sci, Paris, 128, 1417.

Dishon, T., Rosenmann, E., Durst, A. \& Boss, J. H. (1970) Sex hormone dependent antigens of accessory genital glands in the urine of male rats. Am. F. Physiol. 219, 92.

Flocks, R.H., Bandhaur, K., Patex, C. \& Begley, B. J. (1962) Studies on spermagglutinating antibodies in antihuman prostate sera. 7 . Urol. 87, 475.

FreUnd, J. \& Thompson, G. E. (1957) Toxic effects of fluid from the coagulating gland of the guinea pig. Proc. Soc. exp. Biol. Med. 94, 350.

Grabar, P. \& Williams, G. A. (1953) Méthode permettant l'étude conjugée des propertés electrophorétique d'un mélange de proteins. Application au serum sanguin. Biochim. biophys. Acta, 10, 193.

GreEnstein, J. S. \& HaRT, R. G. (1964) The effects of removal of the accessory glands separately or in paired combinations on the reproductive performance of the male rat. Proc. 5th Int. Congr. Anim. Reprod. \& A. I., Trento, 3, 414 .

Otani, Y., Behrman, S. J., Porter, G. W. \& Nakayama, M. (1963) Reduction of fertility in immunized guinea pigs. Int. J. Fert. 8, 835.

Rosenmann, E., Dishon, T. \& Boss, J. H. (1969) Excretion of accessory genital glands-specific antigens in the urine of healthy male rats. F. Lab. clin. Med. 74, 31 .

Rosenmann, E., Dishon, T. \& Boss, J. H. (1971) Humoral antibody response in female rats to antigens of male accessory sex glands. Effects of circulating antibodies on fertility. Int. F. Fert. 16, 113.

Rosenmann, E., Dishon, T., Durst, A. \& Boss, J. H. (1970) Patterns of distribution and urinary excretion of male rat accessory sex gland-specific antigens. F. Reprod. Fert. 23, 383. 